\title{
A Rare Complication of Anticoagulant Use: Colonic Intramural Hematoma-Case Report
}

\section{Antikoagülan Kullanımının Nadir Bir Komplikasyonu: Kolonik İntramural Hematom-Olgu Sunumu}

\author{
(1) Serdar Özdemir \\ Ümraniye Training and Research Hospital, Clinic of Emergency Medicine, İstanbul, Turkey
}

\section{HIIIIII ABSTRACT}

Oral anticoagulants are used in the treatment of cardiac and thromboembolic diseases. Thromboembolic and hemorrhagic complications are seen in the use of medicine. In this case report, we report the case of colonic intramural hematoma due to warfarin use treated conservatively in the light of the literature.

Keywords: Anti coagulant, intramural hemotoma, warfarin, case report

\section{||l||||||| ÖZ}

Oral antikoagülanlar, kardiyak ve tromboembolik hastalıkların tedavisinde kullanılmaktadır. İlacın kullanımında tromboembolik ve hemorajik komplikasyonlar görülmektedir. Bu olgu sunumunda, varfarin kullanımına bağlı gelişen konservatif olarak tedavi edilen kolonik intramural hematom olgusunu literatür eşliğinde sunmaya amaçladık.

Anahtar Kelimeler: Anti koagülan, intramural hematom, varfarin, olgu sunumu

\section{Introduction}

Oral anticoagulants are currently widely used in the treatment of atrial fibrillation, deep vein thrombosis, pulmonary embolism, hypercoagulability syndromes, and in case of heart valve replacement. However, the use of anticoagulants leads to an increased risk of bleeding. The risk of bleeding is increased by $1-3 \%$ for each year of anticoagulant use. ${ }^{1}$ International Normalized Ratio (INR) monitoring should be done regularly. Awareness about the use of the drug should be established to reduce the risk of bleeding. Intracranial, gastrointestinal, and intraabdominal hemorrhages due to anticoagulant use can be seen; however, intestinal intramural hematoma (IMH) is a rare condition. While the incidence of small bowel IMH with anticoagulant use is estimated to be $1 / 25.000$, colonic IMH is rarer. ${ }^{2}$ In this case report, we aimed to investigate a case of colonic IMH due to warfarin overdose presenting with acute abdominal pain.

\section{Case Report}

An 89-year-old female patient was admitted to the emergency department with complaints of abdominal pain and diarrhea for about two days. It was learned from the anamnesis that she had a lung mass and used warfarin for deep vein thrombosis for a month. It was also learned that no laboratory examination was performed since she started using warfarin. On admission, the patient's blood pressure was 95/58 $\mathrm{mmHg}$, and the pulse was 113 beats/min. On physical examination, skin turgor and tonus were decreased, and abdominal tenderness was present. In the rectal examination, the rectum was empty, and a watery stool without hemorrhage was observed in the patient's diaper.

Address for Correspondence/Yazışma Adresi: Serdar Özdemir MD, 
INR was measured as 14.93, and creatinine was $1.35 \mathrm{mg} /$ $\mathrm{dL}$. The hemoglobin value as $11.8 \mathrm{~g} / \mathrm{dL}$ and the hematocrit was $35.7 \%$. Other biochemical parameters were within normal limits. Abdominal ultrasonography showed marked wall thickening in the sigmoid colon. Abdominal computed tomography showed IMH in the terminal ileum and sigmoid colon (Figure 1). No intra-abdominal fluid and hematoma was observed. The INR value decreased to 1.66 , and hemoglobin value was $11.1 \mathrm{~g} / \mathrm{dL}$, and hematocrit was $34.9 \%$ after two units of fresh frozen plasma transfusion. After pain control, the patient was hospitalized. Anticoagulant treatment was stopped. After 24 hours of follow-up, lowmolecular-weight heparin therapy was initiated. The patient was discharged after two days without pain.

\section{Discussion}

Gastrointestinal system IMHs develop spontaneously or due to blunt trauma. The cases caused by blunt trauma are usually in duodenum due to the anatomic location of the retroperitoneum. ${ }^{3}$ In the literature, IMH was first described by McLauchlan in 1838 at the level of the duodenum. ${ }^{3}$ Spontaneous hematoma cases are caused by anticoagulant use or bleeding disorders. It is thought that $36 \%$ of all gastrointestinal IMHs are due to anticoagulant use. ${ }^{3}$ IMHs occur with different symptoms and signs, depending on the level of the gastrointestinal system. Gastric IMH may present as an infrequent complication of anticoagulant use with upper abdominal pain and vomiting with or without hemorrhage. ${ }^{4}$ A duodenal IMH may present with clinical and laboratory findings of jaundice and/or acute pancreatitis. ${ }^{3,5}$ The patients can admit with obstruction at the level of the small intestine and colon. ${ }^{6}$ In addition, abdominal pain is the most common symptom. ${ }^{7}$ Our patient was admitted with abdominal pain and diarrhea. In patients with IMH, hemorrhage is frequently caused by slowly bleeding vessels at the submucosal level. In the presence of anticoagulant toxicity, the increased wall thickness in the gastrointestinal

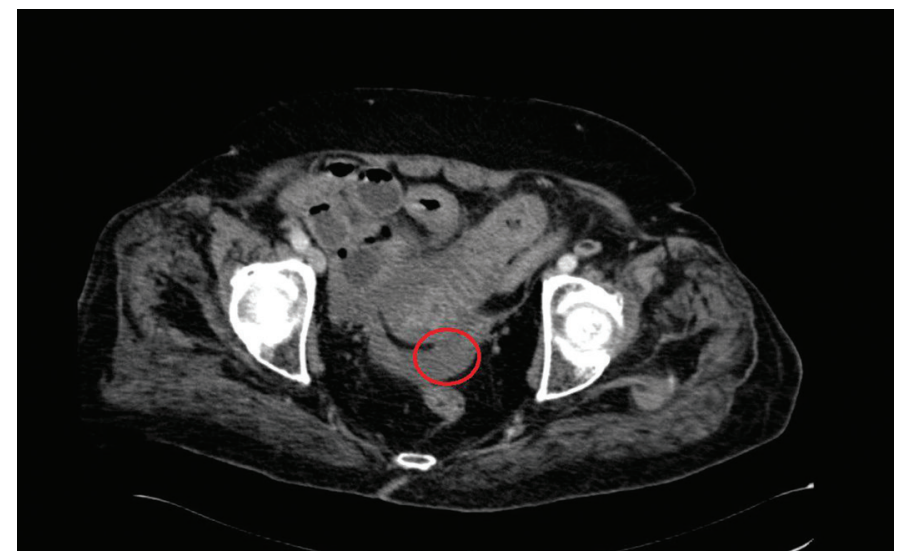

Figure 1. Abdominal computed tomography

*Intramural hematoma in the sigmoid colon tract on computed tomography is characteristic. ${ }^{8}$ Diagnosis is difficult without advanced radiological imaging. Cases with diagnostic laparotomy have been described in the literature. ${ }^{6}$ The first thing that should be done in the treatment of IMH is to stop anticoagulants and to give fresh frozen plasma and vitamin $\mathrm{K}$ to correct coagulation parameters. Conservative treatment is the primary treatment approach, but surgical treatment should be performed in the presence of obstruction, necrosis, or signs of peritonitis. ${ }^{7}$ In patients undergoing laparotomy, a diversion stoma is a treatment option. ${ }^{6}$ The complete resolution of the hematoma is between 10 days and two months. The anticoagulants should be initiated after the complete resolution of the hematoma. If anticoagulant use is required, low molecular weight heparin should be preferred, as in our case. Recurrence of hematoma has been reported in patients in whom anticoagulant treatment is initiated without complete resolution of the hematoma. ${ }^{9}$ In conclusion, IMH is a rare complication of anticoagulant use. Although these cases present with acute abdomen or mechanical intestinal obstruction, they should be treated conservatively.

\section{Ethics}

Informed Consent: Was obtained.

Peer-review: External peer-reviewed.

Financial Disclosure: The author declared that this study received no financial support.

\section{References}

1. Gomes T, Mamdani MM, Holbrook AM, Paterson JM, Hellings C, Juurlink DN. Rates of hemorrhage during warfarin therapy for atrial fibrillation. CMAJ 2013;185:E121-127.

2. Fischer J, Samson P, Robertson MG. Anticoagulant-induced intramural haematoma of the caecum mimicking a colonic tumour. New Zealand Medical Journal 2010;123:75-77.

3. Oliveira JHB, Esper RS, Ocariz RC, Sartori FS, Freire LMD, Chaim EA, et al. Intramural duodenal hematoma secondary to pancreatitis: case report and review of the literatüre. Sao Paulo Med J 2018;136:597-601.

4. Dhawan V, Mohamed A, Fedorak RN. Gastric intramural hematoma: a case report and literature review. Can J Gastroenterol 2009;23:19-22.

5. Basir N, Chong VH. Spontaneous intramural duodenal haematoma with transient biliary obstruction and acute cholecystitis. Singapore Med J 2010;51:e198-200.

6. Lobo L, Koudki R, Prasad Hl K, Shetty B. Colon Obstruction due to an Anticoagulant Induced Intramural Haematoma; A Rare Case Report. J Clin Diagn Res 2013;7:739-741.

7. Mohamed B, Mohamed AS, Philippe-Abrahim K, Robert C, Khaled K. Nontraumatic intramural hematomas in patients on anticoagulant therapy: Report of three cases and overview of the literatüre. Afr J Emerg Med 2014:4:el-e4.

8. Thomas R, Banky B, Hobday C, Borowski DW. Colonic obstruction caused by intraluminal haematoma. BMJ Case Rep 2012;2012.

9. Kwon K, Cheung DY, Seo Y, Kim SB, Bae KN, Kim HJ, et al. Supportive Management Resolved a Colonic Intramural Hematoma in an Anticoagulant User. Intern Med 2014;53:1505-1509. 